\title{
Characterization of Blending Composition Variations in Fatty Acid Methyl Ester (FAME) Biofuels With Diesel to Biodiesel
}

\author{
Yusabri $^{1,2^{*}}$ Muhammad Yerizam ${ }^{3}$ Aida Syarif ${ }^{4}$ \\ ${ }^{I}$ Applied Master of Renewable Energy Engineering, Politeknik Negeri Sriwijaya, Jalan Srijaya Negara, Palembang, \\ 30139 Indonesia. \\ ${ }^{2}$ Crude Distillation and Gas Plant Production, PT. Pertamina (Persero) Refinery Unit III, Jalan Beringin, Kompleks \\ Pertamina Refinery Unit III Plaju, Palembang, 30268 Indonesia. \\ ${ }^{3}$ Chemical Engineering Department, Politeknik Negeri Sriwijaya, Jalan Srijaya Negara, Palembang, 30139 \\ Indonesia. \\ ${ }^{4}$ Renewable Energy Engineering Department, Politeknik Negeri Sriwijaya, Jalan Srijaya Negara, Palembang, \\ 30139 Indonesia. \\ *Corresponding author. Email: yusabri@pertamina.com
}

\begin{abstract}
The increase in national fuel consumption has an impact on the decline in fossil energy reserves. Therefore, one of the solutions to overcome this problem is to look for alternative fuels, such as biosolar or biodiesel. This biodiesel is environmentally friendly, has no effect on health, can be used as vehicle fuel, which has reduced emissions compared to conventional diesel oil. This alternative fuel is produced from various blending composition formulations of Fatty Acid Methyl Ester (FAME) derived from vegetable palm and petroleum diesel oil. Also, it is in accordance with the quality standards from the Directorate General of Oil and Gas. Furthermore, it is used to reduce diesel consumption. This research began by making biodiesel through blending FAME with diesel fuel of varied composition, such as B20, B-30, B-40, B-50, B-60, B-70, B-80 and B-90. Also, the biodiesel characteristics were analyzed, such as the density, viscosity, Calculate Cetane Index (CCI), flash point, water content, and sulfur content. The results showed that the characteristics produced during 30 days storage in accordance with the standards started from B-20, B-30, B40 and B-50. In B-20, the density was $836,000 \mathrm{~kg} / \mathrm{m}^{3}$, viscosity was $2,695 \mathrm{cSt}$, CCI was 50.8 , flash point was at 62 ${ }^{0} \mathrm{C}$, water content was $238 \mathrm{ppm}$, and sulfur content was $790 \mathrm{ppm}$. Furthermore, in B-30, the density was 852,500 $\mathrm{kg} / \mathrm{m}^{3}$, viscosity was $3,157 \mathrm{cSt}$, CCI was 48,3 , flash point was at $69{ }^{\circ} \mathrm{C}$, water content was $241 \mathrm{ppm}$, and sulfur content was $700 \mathrm{ppm}$. In B-40, the density was $856,500 \mathrm{~kg} / \mathrm{m}^{3}$, viscosity was $3,389 \mathrm{cSt}$, CCI was 48,7 , flash point was at 75 ${ }^{0} \mathrm{C}$, water content was $288 \mathrm{ppm}$, and sulfur content was $740 \mathrm{ppm}$. Lastly, in B-50, the density was $858,000 \mathrm{~kg} / \mathrm{m}^{3}$, viscosity was $3,453 \mathrm{cSt}$, CCI was 53,9 , flash point was at $81{ }^{\circ} \mathrm{C}$, water content was $331 \mathrm{ppm}$, and sulfur content was $780 \mathrm{ppm}$.
\end{abstract}

Keywords: Biodiesel, blending, composition, characterization, variation

\section{INTRODUCTION}

Energy and mineral resources data in 2014 stated that dependence on fossil source, especially petroleum is still high at $96 \%$ (petroleum $48 \%$, gas $18 \%$, and coal $30 \%$ ) of total consumption, and efforts to maximize the use of renewable energy have not been implemented as planned [1]. The high use of fossil fuel is caused by people who are wasteful in using energy. Meanwhile, Indonesia is facing a decline in fossil energy reserves, and has not been matched by the discovery of new alternatives. In line with the increase in consumption, the supply of primary energy has also increased. Between 2015-2050, the need for biodiesel will develop [2]. Therefore, based on these conditions, the research effort was made to produce high amounts of biodiesel in a short time.

In order to fulfill the increasing demands, one of the steps taken by the government was implementing a mandatory use of biofuels, especially biodiesel. This has been regulated in the Indonesian Minister Regulation of Energy and Mineral Resources No. 12/2015 regarding 
the third amendment of the regulation number 32 of 2008 about the supply, utilization, and trade system of biofuels. Furthermore, in the same regulation No. 41/2018 regarding the supply and utilization of biodiesel in the framework of financing by the oil palm fund management agency. Subsequently, it has been regulated in the Minister of Energy and Mineral Resources Decree No. 1936 K10/MEM/2018 regarding the procurement of biodiesel for mixing general types of fuel oil from September to December 2018.

\section{MATERIAL AND METHOD}

\subsection{Material and Equipment}

The materials used are FAME and diesel, while the equipment used for analyzing the materials and biodiesel product parameters consisted of a viscometer, density meter, flash point tester, X-ray sulfur, karl fisher moisturemeter, oven, and analytical balance.

\subsection{Sampling Method}

The biodiesel was made by blending FAME (20 $\mathrm{mL})$ with diesel $(80 \mathrm{~mL})$ in a digital stirrer tank. Therefore, a $20 \%$ blending composition was obtained called B-20, and the FAME was called B-100. The manufacture of biodiesel with the blending composition of B-30, B-40, B-50, B-60, B-70, B-80 and B-90 was achieved by making B-20 biodiesel in accordance with the volume ratio of each composition.

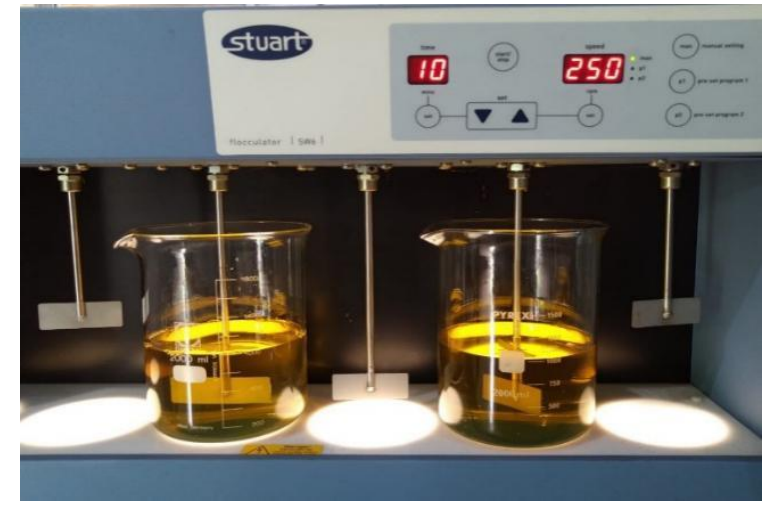

Figure 1. Blending FAME Process with Diesel on a Digital Stirrer

Mixing was carried out for 10 minutes in a digital mixer. Meanwhile, the blended biodiesel products were stored in glass storage bottles at room ambient temperatures.

\subsection{Sample Testing}

The blended biodiesel products were then analyzed for quality which includes density, viscosity, cetane number or CCI, flash point, water content, and sulfur content.

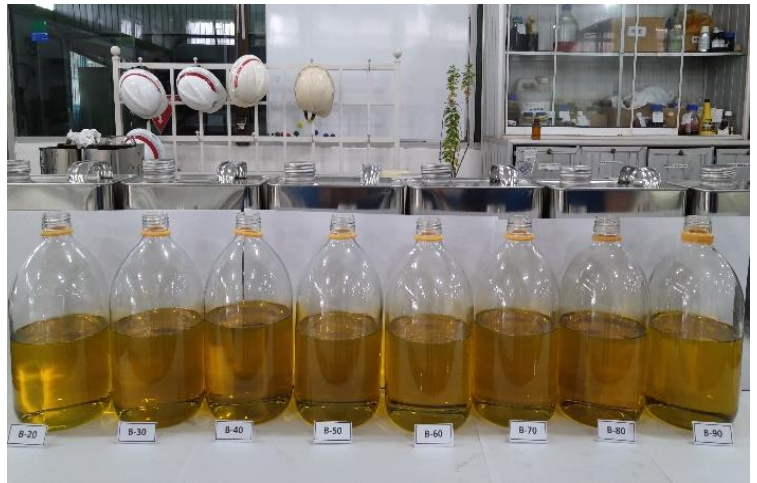

Figure 2. Biodiesel Product

Testing was then carried out every week during 1 month storage of the biodiesel products. Meanwhile, the characteristics analysis was carried out on the first day after 2 hours of blending process. Also, further analysis was conducted after the next 7 days. Likewise, the 2nd, $3 \mathrm{rd}, 4 \mathrm{th}$, and 5 th analysis was conducted to determine the biodiesel quality after 1 month storage. This was achieved by comparing the quality on the first day with that of every week until 1 month. Therefore, the effect of storage time on the quality was determined.

\section{RESULTS AND DISCUSSION}

\subsection{Biodiesel Density in Various Blending Composition Variations during 30 Days}

Density is one of the important parameters that should be known regarding fuel [3]. This is because it is related to the carbon chain of alkyl ester. Therefore, the longer the chain, the more the density. This is also accompanied by a decrease in the degree of molecular saturation [4].

Also, density affects the heating value and the power produced by the fuel combustion process. Therefore, a high value indicates the number of components of the fuel. This will extend the atomization process of the constituents during combustion, which will increase the heating [5].

The density required for biodiesel according to the Directorate General of Oil and Gas is $815-860 \mathrm{~kg} / \mathrm{m}^{3}$ at $15{ }^{0} \mathrm{C}$. According to Hadrah, et al. (2018), the density value that is in accordance with the required quality standards can produce a complete combustion reaction in the engine, while a value that exceeds the standards will cause an incomplete combustion reaction, which will increase emissions and thirst in the engine [6].

Figure 3 showed that the increase in density is accompanied by a higher FAME composition. Meanwhile, the biodiesel density value is higher than diesel. Therefore, this will affect the density as long as the blending formulation is carried out by increasing the FAME composition. 
Also, the blending composition with density values included in the quality standards is a formulation of B20, B-30, B-40, and B-50. Furthermore, the results of the analysis were obtained between the required minimum and maximum quality standards. Meanwhile, the formulations of B-60, B-70, B-80 and B-90 obtained values that are above the maximum of the quality standard limits. Therefore, based on the storage time, the density value of the products tends to be stable for one month.

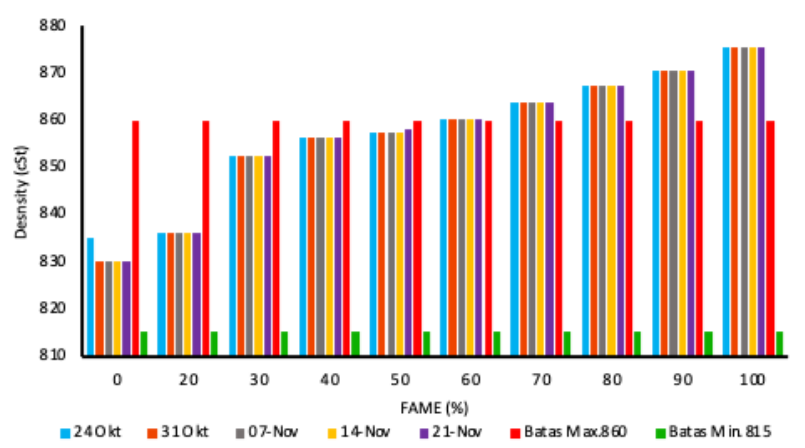

Figure 3. Biodiesel Density in Various Blending Composition Variations during 30 Days

\subsection{Biodiesel Viscosity in Various Blending Composition Variations during 30 Days}

Viscosity determines the thickness level of fuel oil. Therefore, it can be determined using the falling ball method [7]. The kinematic viscosity of FAME is almost a double of diesel, and very important for engine lubricity. Meanwhile, the vegetable ingredients are relatively low in sulfur and aromatic content. Therefore, the emission level produced is also lower in terms of its particulate matter (PM).

A high viscosity is associated with difficulty in the pumping and ignition process. However, when it is too runny, the fuel will be difficult to burn, and may cause leakage in the injection pipe [8].

Meanwhile, high viscosity will increase the friction in the pipe, aggravate the pump work, and complicate the filtering process. This will in turn increase the possibility of dirt being deposited [9].

Based on the Directorate General of Oil and Gas, the required viscosity of biodiesel is $2.0-4.5 \mathrm{cSt}$ at 40 ${ }^{0} \mathrm{C}$. Also, the addition of FAME composition in the blending formulation have an impact on the viscosity of the products. This is because diesel has a lower viscosity than FAME. When mixed, the biodiesel will have a viscosity lesser than FAME, but not less than diesel. Therefore, increasing FAME compositions in the blending formulation will increase the viscosity of the blending results.

Figure 4 showed there is an increase in viscosity every week at room temperature. This is caused by oxidation and polymerization in biodiesel products. This oxidation process causes the formation of hydroperoxides, which can be polymerized. Based on the viscosity analysis, the formulations of B-20, B-30, B-40, B-50, B-60, B-70, B-80 and B-90 are still within the specified quality requirements.

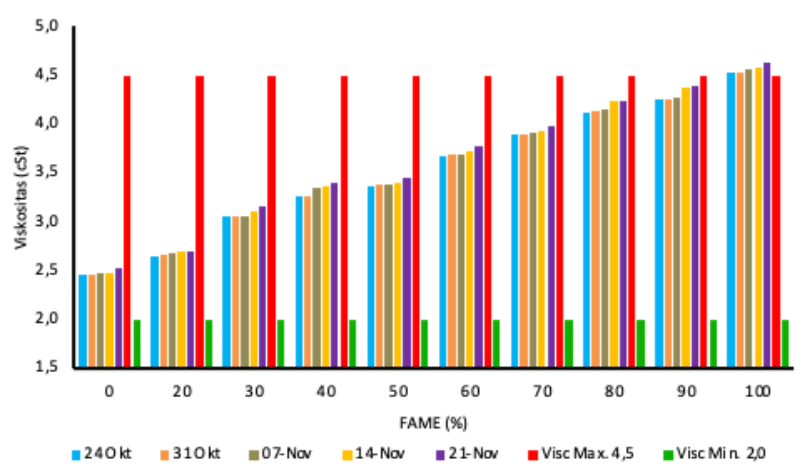

Figure 4. Biodiesel Viscosity in Various Blending Composition Variations during 30 Days

Figure 4 showed there is an increase in viscosity every week at room temperature. This is caused by oxidation and polymerization in biodiesel products. This oxidation process causes the formation of hydroperoxides, which can be polymerized. Based on the viscosity analysis, the formulations of B-20, B-30, B-40, B-50, B-60, B-70, B-80 and B-90 are still within the specified quality requirements.

\subsection{Calculated Cetane Index (CCI) Biodiesel in Various Blending Composition Variations during 30 Days}

Besides sulfur, an indicator of the fuel quality is cetane number. Hence, the higher this number, the better the quality. Therefore, a good quality diesel will result in good performance, more durable motor, and better exhaust emissions.

The cetane number or CCI of FAME is higher than diesel fuel, therefore it is very good for improving autoignition performance on diesel engines. Also, the longer the carbon chain of fatty acids and the more saturated molecules, the higher the cetane number [10].

Furthermore, the higher the cetane number, the faster the combustion, and the better the thermodynamic efficiency. A high cetane number has a significant effect on the short time between fuel injection and initiation, hence causing a good start and smooth engine sound [11].

Muryama (2000) reported that vegetable oil had greater engine efficiency and power compared to diesel, because the resulting exhaust gas temperature was lower. Also, there was a decrease in the average heating value quality by $2 \%$.

According to the SNI-04-7182-2015 standard, biodiesel or FAME requirement for a minimum cetane rate is 51 [12]. Meanwhile, according to the Directorate General of Oil and Gas, diesel fuel has a minimum cetane rate of 48 . Therefore, the emissions generated 
from biodiesel are cleaner, environmentally friendly, and biodegradable. Furthermore, the emissions of particulates, soot, and carbon monoxide are lower than biodiesel compared to petroleum-based diesel fuel.

Based on the products from the blending process, only the B-20 formulation can be tested using the ASTM D613-80 method to obtain its cetane number. Meanwhile, because of the high density values of B-30, B-40, B-50, B-60, B-70, B-80 and B-90, it is feared that they will cause damage to the laboratory analysis machines. The ASTM D613-80 method is a measurement for determining the quality of biodiesel combustion or the cetane number of diesel fuel. Therefore, the formulations of B-30, B-40, B-50, B-60, B-70, B-80 and B-90 can be calculated by finding the $\mathrm{CCI}$ value as a substitute for the cetane numbers.

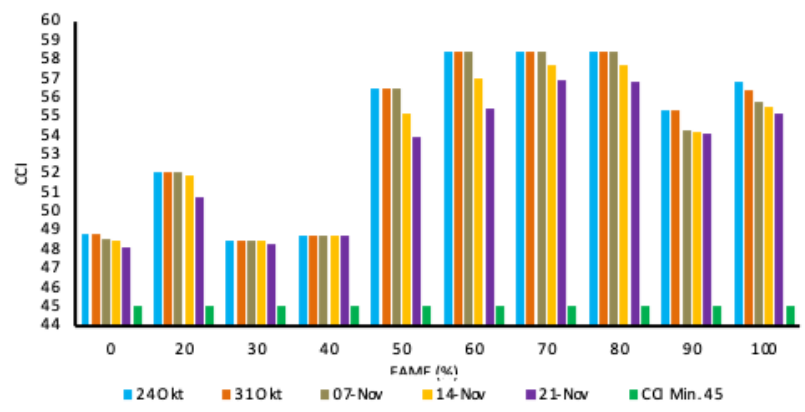

Figure 5. Biodiesel CCI in Various Blending Composition Variations during 30 Days

Based on the analysis of the products, the CCI value was above the minimum limit required by the Directorate General of Oil and Gas. Also, the high FAME composition increased the cetane number of the products. Based on Figure 5, CCI increased along with the higher FAME composition. However, there was a decrease in each week during 1 month storage.

\subsection{Biodiesel Flash Points in Various Blending Composition Variations during 30 Days}

The flash point was determined using a PenskyMartens closed cup instrument [13]. These characteristics needs to be known because it affects the process of storing biofuel products. Therefore, a low flash point will make the storage process difficult because of its relatively high flammability. Meanwhile, a high flash point will complicate the fuel during ignition [14].

The presence of methanol in biodiesel products lowers the flash point, hence it is flammable. Therefore, products with low viscosity values have low flash points [7]. This is because fluids with high viscosity are more difficult to ignite. Hence, according to the quality requirements, the flash point is set with a minimum value of $52{ }^{\circ} \mathrm{C}$ for petroleum-based diesel fuel.

Also, the flash point of FAME is higher than diesel, therefore the blending formulation with more
FAME composition will result in biodiesel with an increased flash point. Therefore, a higher value guarantees safer treatment and storage of the products [15].

In Figure 6, the flash point increased in each composition. It also increased every week for 1 month of storage time. Therefore, regarding the requirements, the flash point of each composition has exceeded the mingin um required threshold.

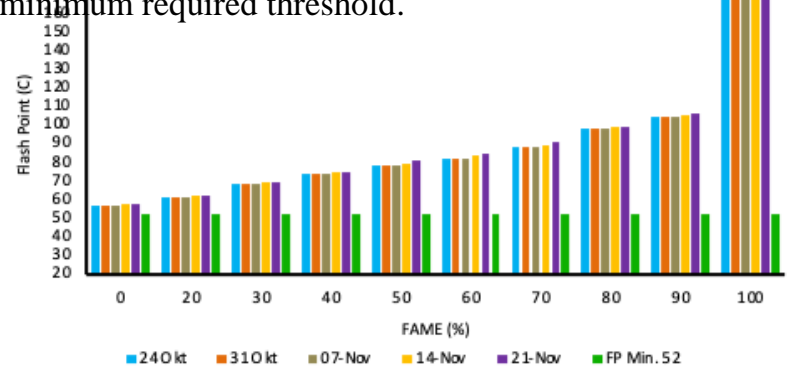

Figure 6. Biodiesel Flash Points in Various Blending Composition Variations during 30 Days

\subsection{Biodiesel Water Content in Various Blending Composition Variations during 30 Days}

In some countries during winter, the water content in diesel may form crystals that can block the fuel flow into the engine injector. Furthermore, water can cause corrosion and growth of micro-organisms which can also block fuel flow into the combustion chamber. In addition, sediments can cause blockage and damage to the engine [16].

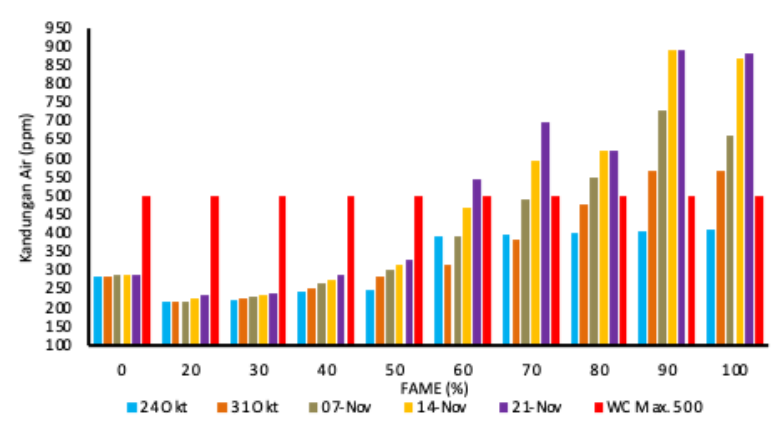

Figure 7. Biodiesel Water Content in Various Blending Composition Variations during 30 Days

Based on the analysis of blending composition of FAME and diesel fuel, the water content data was below the maximum quality requirements set on the first day, which increased every week. However, it was above the maximum quality requirements after 1 month of storage or analysis on November 21 starting from B-60, B-70, B-80, and B-90. Overall, with the higher FAME composition, the water content also increased. This was caused by the properties and characteristics of FAME, which is hydroscopic and easily dissolve in water. 
Based on the overall composition variation of FAME in B-60, B-70, B-80 and B-90, the water content value was above the maximum limit required after 1 month of storage.

\subsection{Biodiesel Sulfur Content in Various Blending Composition Variations during 30 Days}

Sulfur is the main impurity of diesel engines, because a high content will result in excess acid levels. This will in turn damage the engine components, ranging from crust to the fuel lines. In fact, this can disrupt the fuel supply flowing into the cylinder. Therefore, the direct effect is the disruption of engine performance, ranging from reduced power to more serious damage. Furthermore, premature combustion or knocking may occur which can cause the engine to tickle.

A high sulfur content can also damage the injector components and cause poor combustion. Meanwhile, a lower content will result in a cleaner exhaust, fuel lines, filters, and combustion chamber. Also, sulfur influences engine life. Therefore, the higher the sulfuric acid content, the more easily it will rust.

The effect due to high sulfur levels in diesel fuel does not only damage vehicle engine. In the case of air pollution, combustion gases from the engine when mixed with air will form sulfur dioxide $\left(\mathrm{SO}_{2}\right)$. When this $\mathrm{SO}_{2}$ is mixed with water vapor, it leads to acid buildups which is harmful to the body [17-18].

Also, FAME does not contain nitrogen or aromatic compounds, but only less than 155 ppm (parts per million) of sulfur (Directorate General of Oil and Gas). Furthermore, it has $11 \%$ oxygen in weight percent, which causes a reduction in energy content, but reduces the levels of exhaust emissions in the form of carbon monoxide (CO), hydrocarbons ( $\mathrm{HC})$, particulates and soot [19-21]. Also, the energy content of biodiesel or FAME is $10 \%$ lower when compared to diesel fuel. Therefore, the efficiency can be said to be the same as petroleum-based fuel. This means the power and torque produced are proportional to the heating value of the combustion.

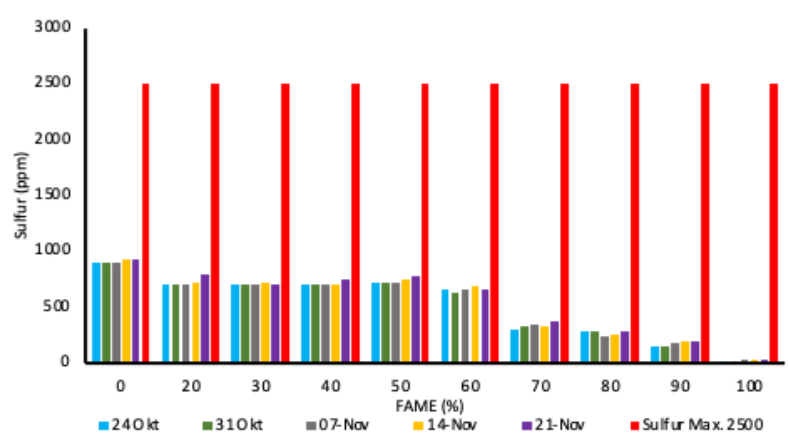

Figure 8. Biodiesel Sulfur Content in Various Blending Composition Variations during 30 Days
Blending analysis with composition variations of FAME and diesel showed that biodiesel products are environmentally friendly because they produce better exhaust emissions without sulfur. Meanwhile, sulfur value at $<0.1 \% \mathrm{~m} / \mathrm{m}$ was far below the maximum limit of the quality requirements, which was $0.25 \% \mathrm{~m} / \mathrm{m}$.

Figure 8 also showed that the sulfur content had no effect on storage time. This can be seen from the value, which does not change every week. Therefore, the higher the FAME composition, the lesser the sulfur content.

Based on the overall blending analysis with composition variations of FAME and diesel fuel, the sulfur content was far below the maximum quality requirements.

\section{CONCLUSION}

Based on this research, the composition of biodiesel products in accordance with the quality standards after one month storage was B-20, B-30, B-40 and B-50, with density values between the required minimum and maximum quality. The B-20 composition had a density of $836,000 \mathrm{~kg} / \mathrm{m}^{3}$, viscosity of $2,695 \mathrm{cSt}$., CCI of 50,8, flash point at $62{ }^{\circ} \mathrm{C}$, water content of 238 ppm, and sulfur content of $790 \mathrm{ppm}$. Furthermore, the B-30 composition had a density of $852,500 \mathrm{~kg} / \mathrm{m}^{3}$, viscosity of $3,157 \mathrm{cSt}, \mathrm{CCI}$ of 48.3 , flash point at $69{ }^{\circ} \mathrm{C}$, water content of $241 \mathrm{ppm}$, and sulfur content of 700 ppm. Also, B-40 composition had a density of 856,500 $\mathrm{kg} / \mathrm{m}^{3}$, viscosity of $3,389 \mathrm{cSt}, \mathrm{CCI}$ of 48.7 , flash point at $75{ }^{\circ} \mathrm{C}$, water content of $288 \mathrm{ppm}$, and sulfur content of $740 \mathrm{ppm}$. In addition, B-50 had a density of 858,000 $\mathrm{kg} / \mathrm{m}^{3}$, viscosity of $3,453 \mathrm{cSt}, \mathrm{CCI}$ of 53,9 , flash point at $81{ }^{\circ} \mathrm{C}$, water content of $331 \mathrm{ppm}$, and sulfur content of $780 \mathrm{ppm}$.

Based on the several tested parameters, the water content is one of the critical characteristics that have significantly increased compared to the storage time. This is inversely proportional to the CCI value which showed a decrease during storage time, but tends to reduce with increase in FAME composition.

\section{REFERENCES}

[1] Hutapea. 2016. Solusi Listrik Off-grid berbasiskan energi terbarukan di Indonesia, Kerangka regulasi dan program, Jakarta.

[2] Fitriana, Ira, Anindhita, Agus Sugiyono, Laode M.A. Wahid, Adiarso. 2017. Outlook Energi Indonesia. Inisiatif Pengembangan Teknologi Energi Bersih, Badan Pengkajian dan Penerapan Teknologi Pusat, Teknologi dan Sumber Daya Energi dan Industri Kimia, Jakarta.

[3] RA Nurul Moulita, Rusdianasari, L Kalsum. 2019. Converting Waste Cooking Oil into Biodiesel using Microwaves and High Voltage Technology, Journal of Physics: Conf. Series 1167(012033).

[4] Moecke, Elisa Helena Siegel, Rafael Feller, H. A. Dos Santos, M. De Madeiros Machado, A. L. 
Vieira Cubas A. R. De Aquira Dutra, L. L. Vieira Santos, dan S. R. Soares. 2016. Biodiesel Production from Waste Cooking Oil for.

[5] Rusdianasari, A Syarif, M Yerizam, MS Yusi, L Kalsum, Y Bow. 2020. Effect of Catalyst on the Quality of Biodiesel from Waste Cooking oil by Induction Heating, Journal of Physics: Conf. Series 1500 (012052).

[6] Hadrah, Monik K and Fitria Mayang S 2018. Analysist of Waste Cooking Oil as Biodiesel Fuel Using Transesterification Process Jurnal Daur Lingkungan Vol 1 [1] p 16-21.

[7] S Yunsari, Rusdianasari, A Husaini. 2019. CPO Based Biodiesel Production using Microwaves Assisted Method, Journal of Physics: Conf. Series 1167(1) 012036.

[8] Evy S and Fatmir E 2012. Technology Processing of Biodiesel from Used Cooking Oil by Microfiltration and Transesterification Techniques as an Alternative Fuel of Diesel Engine. Jurnal Riset Industri Vol 6 No 2 p 117-127.

[9] Moeksin, Rosdiana, M. Zaki Shofahaudy, dan Dyah Pratiwi Warsito. 2017. Pengaruh Rasio Metanol dan Tegangan Arus Elektrolisis Terhadap Yield Biodiesel dari Minyak Jelantah. Indralaya: Jurusan Teknik Kimia Fakultas Teknik Universitas Sriwijaya.

[10] Bello, Emmanuel I, Taye S Mogaji dan Agge Makanju. 2011. The Effects of Transesterification on Selected Fuel Properties of Three Vegetable Oils, Journal of Mechanical Engineering Research 3(7): 218-25.

[11] Mittelbach, M and Remschmidt, C. 2004. Biodiesel: The Comprehensive Handbook, Third edition: Boersedruck Ges: Austria.

[12] Badan Standarisasi Nasional. 2015. Standar Nasional Indonesia Biodiesel 7182-2015. Jakarta. www.bsn.go.id.

[13] S Susumu, R Rusdianasari, S Yusi. 2018. Biodiesel Production from Waste Cooking Oil using
Electrostatic Method, Indonesia Journal of Fundamental and Applied Chemistry (IJFAC) 3(3).

[14] RAN Moulita, R Rusdianasari, L Kalsum 2020. Biodiesel Production from Waste Cooking Oil using Induction Heating Technology, Indonesia Journal of Fundamental and Applied Chemistry (IJFAC) 5(1).

[15] Keera S. T., S. M. El Sabagh, dan A. R. Taman. 2018. Castor Oil Biodiesel Production and Optimization, Egyptian Journal of Petroleum 27(4): 979-84.

[16] Hendartomo, T. 2006. Pemanfaatan Minyak dari Tumbuhan Untuk Pembuatan Biodiesel. Penerbit Universitas Gajahmada. Yogyakarta.

[17] Rusdianasari, Y Bow, RAN Moulita 2020. Temperature Effect on the Biodiesel Quality from Waste Cooking Oil by Induction Heating, Journal of Physics: Conf. Series 1450012003.

[18] S Yunsari, A Husaini, R Rusdianasari 2019. Effect of Variation of Catalyst Concentration in the Producing of Biodiesel from Crude Palm Oil using Induction Heater, Asian Journal of Applied research for Community Development and Empowerment (AJARCDE).

[19] R Ploetz, R Rusdianasari, and E Eviliana 2016 Renewable Energy: Advantages and Disadvantages, Proceeding Forum in Research, Science, and Technology (FIRST).

[20] Erniati Anzar, M. Syahirman Yusi, Yohandri Bow. 2018. Purification of Glycerol from Biodiesel byProduct by Adsorption using Bentonite. Indones. J. Fundam. Appl. Chem (IJFAC)., vol. 3, no. 3, pp. 83-88.

[21] J. U. Putra, L. Kalsum, and Y. Bow. 2018. Effect of DC Voltage on Prototype of Biodiesel Electrostatic Separator with Glycerin from Waste Cooking Oil', Indones. J. Fundam. Appl. Chem., Vol. 3(3). 